\title{
A comparison of consumer perception towards organized and unorganized retailing in South Gujarat
}

\author{
Swati Sharma, Ruchira Shukla and Alpesh Leua
}

Received : 25.06.2018; Revised : 01.09.2018; Accepted : 12.09.2018

\begin{abstract}
The Indian retail industry is one of the most vibrant industries in the country. The retailing sector in India is one of the pillars of its economy and accounts for 14 to 15 per cent of its GDP. The Indian retail market is estimated to be US\$ 500 billion and one of the top five retail markets in the world by economic value. But despite this growth, the Indian retail industry is highly fragmented, with the organized retailing still at a nascent stage which accounts for far less percentage than the unorganized retailing of the total Indian retail market. It is estimated that organized retailing accounts for less than 5 per cent of today's market. Retailing in India came with evolutionary pattern form unorganised retail store to organised retail store. The global retail industry has been growing at a brisk pace the last few decades. At present sales from the different modern retail centre is higher than unorganised retail store, sales from the organised retail store is more than 45 per cent higher than sales from unorganised retail store. This study aims to find the consumer perception towards organized and unorganized retailing in South Gujarat. The primary data was gathered by administering a prearranged questionnaire with 200 consumers selected purposively from Surat and Valsad city of South Gujarat. The data analysis of consumer attitude towards unorganized and organized retailers shows that there is a difference between the consumers' perception towards both organized retailers and unorganized retailers regarding the shopping environment, promotional schemes, choice/variety of brands, proper parking facility, proper shelf display of the products etc.
\end{abstract}

KEY WORDS : Organised retail, Unorganised retail, Consumer perception

How to cite this paper : Sharma, Swati, Shukla, Ruchira and Leua, Alpesh (2018). A comparison of consumer perception towards organized and unorganized retailing in South Gujarat. Internat. J. Com. \& Bus. Manage, 11(2) : 99-104, DOI: 10.15740/HAS/IJCBM/ 11.2/99-104. Copyright@2018: Hind Agri-Horticultural Society.

\section{MEMBERS OF THE RESEARCH FORUM}

Correspondence to:

Swati Sharma, ASPEE Agribusiness Management Institute, Navsari

Agricultural University, Navsari (Gujarat) India

E-mail: swatisharma_abm@yahoo.co.in

Authors' affiliations:

Ruchira Shukla and Alpesh Leua, ASPEE Agribusiness Management Institute, Navsari Agricultural University, Navsari (Gujarat) India 